\title{
Varieties of Panpsychism
}

\author{
Philip Clayton
}

Panpsychism is not like pregnancy. A woman either is or is not pregnant. In such cases more generally, either $x$ or not- $x$. By contrast, you are not either warm or not warm, tall or not tall, smart or not smart. You can be more or less slow, more or less prompt, more or less witty. The discussion of panpsychism is changed in important and fruitful ways when we recognize that the topic is better understood in the latter way than in the former.

»Panpsychism is Not Like Pregnancy « would have been a strange title for a conference paper. Perhaps the paper would better have been titled »Panpsychism without the >Pan.« At first glance, the panpsychism debate appears to be a question of all or nothing, just as the thief either takes all William's money or he doesn't. But I suggest that we need to think our way beyond this way of approaching panpsychism. Particularly in the context of panentheism, panpsychism should be more complex than, say, the thesis that all levels of evolution can be summarized under the heading of pan-psyche or, following David Ray Griffin, pan-experience. Instead, I will argue, the discussion of God, evolution, and psyche needs to be expanded to include the full variety of qualities, including awareness, intention, goal-directed behavior, mental representation, cognition, and consciousness. Clearly this shift has implications for understanding the nature and scope of metaphysics and theology, a topic to which I shall return at the end of the discussion.

Three things will happen when we return to the panpsychism question after this analysis. We need to have a better grasp of the issues that are raised by the evolution of consciousness. We should be able to specify the sense in which evolution produces qualities that were not actually already in the parts. Finally, we should reach a more complex understanding of the relevance of panentheism to questions of the evolution of consciousness, and hence a more complex understanding of the Divine itself. The upshot is a more limited affirmation of panpsychism, in contrast to the more »maximal « affirmation of the existence of psyche in all things, or all things as psyche.

The qualities that we call mental or proto-mental are extremely diverse. Because the differences are greater than is often acknowledged, I propose calling the result minimal or "gradualist « panpsychism rather than traditional or »maximal« panpsychism. It will not have escaped you that minimal and maximal are terms on a quantitative scale rather than expressions of a forced either/or choice. Panpsychism in this more minimal form, I will argue, is the 
more compelling view; and the quantitative nature of the discussion should help us to more fully nuance the discussion as the debate continues.

First, though, let's get a full sense of the range of questions raised by the topic. If we are going to make progress in areas where stalemates have previously arisen, we will need to understand the questions that need to be raised ... and the questions that are less productive.

\section{Clarifying the Questions}

(1) Mind and mental entities. Of course, many philosophers today doubt whether mentality as such even exists or, more accurately, whether mental states or qualia have a primary rather than derivative existence. Most readers will be well aware of this debate, and some engage in it professionally. For this reason I will not repeat the well-known arguments against the major advocates of physicalism such as Wolf Singer, Francis Crick, and Dan Dennett. Whether anything mental exists may be a major debate, but I don't think it's the topic de jour.

I thus recommend that we begin instead with the assumption that some mental attributes or things exist and exercise causality qua mental. (I will problematize »the mental« in a moment.) Mentality is not merely an epiphenomenon. It is not merely supervenient on physical states, nor is it merely a weakly emergent property of physical matter/energy, where all true causal forces reside.

As the old American metaphor puts it, we have more important fish to fry than reductionism. Leaving aside reductionism at the start will allow us to focus in on a different set of questions. For example: Does finite mentality arise at some point in cosmic evolution, such that it was not actually present at one point in time and then later was? If mentality is emergent, then must it always be linked to something physical, say a body? Do separate mental units, say souls, exist, or are they just multiple manifestations of one mental reality (call it God)? Skrbina puts it nicely:

The central issue here is whether we speak of such mind as »mind of single universal « (God, the Absolute, the World Soul, and so on) or of mind as attributable to each thing in itself (of each object's possessing its own unique, individual mind). The former view would be a monist concept of mind, the latter a pluralist concept. (Skrbina 2005: 21)

Whitehead's famous notion of actual entities (Whitehead 1978) moves in the direction of radical pluralism. Assume for the moment that he is right and that 
an extremely large number of actual entities (AEs) exist. This requires us to think of each such moment of creative becoming as a separate entity or occasion, existing on its own. Of course, one can be a radical pluralist in this way and still hold that AEs are so interdependent that they are internally related. That would mean a radical pluralism of psyches.

The specter of panpsychism poses a further question: does the world contain anything that is non-mental, such as purely physical objects? As suggested at the outset, I strongly resist this either/or frame; it leads too quickly to a simple syllogism:

Some mental things exist.

Nothing exists that is purely physical.

Hence, all things are mental things.

I will suggest that the more interesting discussion is of the varieties of mentality or »psychisms. « Interesting nuances of »psychism « surface when one explores options such as limited panpsychism, emergentist panpsychism, or the panpsychism of potentiality and actuality. They cause us to reflect on the differences, and thus on the status of the unifying concepts.

To proceed in this way is to hypothesize that das Mentale is not an either/ or quality, such that an entity either is mental (has the attribute of mentality) or isn't. (For now I use »a mental entity« and »an entity that has mentality« interchangeably.) It is more fruitful to ask, »To what extent, and in what sense, is this entity mental? «

(2) Panentheism. A series of questions arise at the intersection of panpsychism and panentheism. Some represent difficult challenges for classical panpsychism.

If there is a plurality of mental entities, how is God related to each one? For Whitehead, of course, actual entities are ultimate, not more dependent on God than God is on them. But actual entities could be dependent on God in a stronger way, existing only through the continuing will of God; or they could be real individual expressions of a single divine Spirit (this is the view of the Indian philosopher Ramanuja); or, following Spinoza, what we call individuals might merely be ways that the one divine substance is manifested in a particular time or place-modes of the One. How would one decide between these options?

Panentheism might also raise some critical questions for classical panpsychism. What is God's relationship to finite mental entities if they are really present »all the way down«? If God lures even an electron, what does God lure it to do? Or does theological panpsychism instead support monism? That would mean that the psyches that seem to be in all things are actually just one 
psyche: the one mind of God, or Nous in Plotinus's sense. For that matter, how would one distinguish finite »natural « mentality from infinite divine mentality? Can the one be within the other without compromising the integrity of either? Do classical panpsychisms maintain that it's the God question that supports the dichotomy either everything is mental or nothing is mental and, if so, why?

In contrast, a gradualist panpsychism begins with the question To what extent, and in what sense, is a given entity mental? Formulating this question, one immediately recognizes that the relationships between panpsychism and panentheism are rather more complex than one might have thought. There are no simple entailments: one can be a panpsychist without being a panentheist, for example if one is a pantheist. Conversely, one can be a panentheist without being a panpsychist, for example if one holds that the world is God's (material) body. Above all, gradualist panpsychism shifts the conversation in that one must now ask about the relationship between the panentheistic God and the whole history of emergent mentality.

\section{Emergent Mentality}

Gradualist panpsychism seeks a theory of consciousness that is consonant with the results and the methods of the sciences as well as with human phenomenal experience. Let's call this a theory of emergent mentality. It's the view that the particles and physical states of (say) macrophysics and physical chemistry do not manifest an actual mentality; they do not have intentions, for example. The first self-reproducing cell, by contrast, does have a primitive awareness of its environment. Increasing complexity across biological evolution brings more and more complex awareness, with human consciousness being the most advanced form of embodied awareness that we have yet discovered.

Emergent mentality as I use the term stands in contrast to a classical position such as Whitehead's panpsychism or »panexperientialism.« Famously, Whitehead holds that all units of reality are occasions of creative becoming. Each actual (as opposed to merely potential) entity is thus its own center of experience. If given only a single argument to defend this view, Whiteheadian panpsychists will generally argue that mentality cannot come from something that is non-mental. But Whiteheadians are by no means the only philosophers who object to gradualist theories of mentality. All dualists do, as well as many neuroscientists who are drawn toward exclusively material explanations of thought and consciousness. So let's call this particular critique the »no 
mind from matter « (NMfM) Objection. Thomas Nagel sometimes expresses a similar intuition as fundamental or »schematic « for him: »In its schematic, pre-Socratic way, this sort of monism attempts to recognize the mental as a physically irreducible part of reality.« (Nagel 2012: 62) I will argue that this intuition does not stand up to closer examination, at least not in this particular (non-theistic) form.

Finally, I do not think that theism as such falsifies one option and verifies the other. It is not inconsistent for advocates of most (but not all) forms of theism to affirm either Whiteheadian panpsychism or emergent mentality. But I do think that setting panentheism in dialogue with contemporary philosophy and science supports gradual over maximal panpsychism.

The argument proceeds in four steps.

\section{(1) Evolutionary Mentality and Emergentist Panpsychism}

The evolutionary evidence suggests the emergence of the various phenomena that we call mentality, a position sometimes called emergentist panpsychism. Of the various forms of limited or gradualist panpsychism, this position is in my view the most convincing. Once again, it starts by challenging the assumption that all existing things either are or are not centers of experience. Limiting or conditioning the »pan« in panpsychism is an important part of making this case.

Thomas Nagel is a famous anti-emergentist panpsychist. He argues, for example:

The implausibility of the reductive program that is needed to defend the completeness of ... naturalism provides a reason for trying to think of alternativesalternatives that make mind, meaning, and value as fundamental as matter and space-time in an account of what it. The fundamental elements of physics and chemistry have been inferred to explain the behavior of the inanimate world. Something more is needed to explain how there can be conscious, thinking creatures whose bodies and brains are composed of those elements... . Everything, living or not, is constituted from elements having a nature that is both physical and nonphysical - that is, capable of combining into mental wholes. So this reductive account can also be described as a form of panpsychism. (Nagel 2012: 20, 57)

Nagel and I agree in opposing the reduction to physicalism but disagree concerning when this »something more « is needed. He thinks that, in order to beat physicalism, mind must be fundamental to all things, whereas I argue that the first time it becomes fundamental is in the role it must play to explain selfreproducing cells. From cells on we no longer disagree. 
For the emergentist panpsychist, »mind «-in the minimal form of awareness and goal-directed behavior-is first discernible with the emergence of self-reproducing life; as a concept it only begins to play a role after that. From the birth of cellular agents, the two positions walk side by side. For example, both Godehard Brüntrup and I agree that unicellular organisms possess a rudimentary form of awareness. This awareness is a matter of life and death to the cell. After all, cells can live and reproduce, or they can die. From an evolutionary point of view, they have an interest in living. To move up a glucose gradient and receive more nutrition is in the interest of a unicellular organism; it is »good.« To move toward a toxin is »bad.« The cell's (chemically mediated) awareness of its environment, which differentiates between the two, is of its very essence.

It's fascinating to trace the evolutionary process from primitive awareness and goal-directed behavior at the birth of the biosphere to the most complex conscious cognition and subjective experiences. Note that, once a certain threshhold is passed, the anti-emergentist panpsychist appears to be as willing as the emergentist panpsychist to affirm the emergence of ever more complex mental phenomena.

\section{(2) Mind in potentia}

The more plausible the transition from potential to actual mentality becomes, the more the NMfM Objection is undercut. Although in the end my argument will require a theological dimension, the first step of the argument can be made without it.

Although each cell is aware, each can potentially become part of (say) a human being, a being with the attribute of consciousness. So the cell is potentially conscious if the right circumstances occur; specifically, it is potentially conscious in the sense that it can become part of a whole to which we attribute consciousness (say a human person).

This topic raises some complex dilemmas concerning location and part/ whole relations. Not every property of a whole is a property of its parts (redness), nor is every property of a part also a property of the whole (weighing less than one kilo). But some properties of parts are also properties of the whole (having some weight), just as some properties of a whole may also be properties of its parts (if the whole orchestra is in tune, then each instrument is in tune). Regarding location, it's easier to say »Beth is conscious, though consciousness is not the kind of property that has a location.«Surely consciousness does not have a location in the same way that her hat does; still, if Beth is in California, we wouldn't say that her consciousness resides in Tokyo. Is Beth's consciousness located in each neuron of her brain, or in her brain as a whole, 
in her body as a whole, or in her personhood (whatever that is)? It seems most adequate to say that Beth's consciousness is present in Beth as a whole. Clearly, these philosophy of mind questions are relevant to panentheism as well.

Now consider an analogy. The cell as a whole is aware. And the actual chemical components of a given cell had the potential to become part of that cell. Take for example one of the cytosine molecules (chemical formula $\mathrm{C}_{4} \mathrm{H}_{5} \mathrm{~N}_{3} \mathrm{O}$ ) that pairs with guanine to make up a rung in the DNA double helix. This particular molecule is potentially aware in the sense that, if the right circumstances occur, it becomes part of a whole cell to which we attribute awareness.

The analogy does two things. It treats both consciousness and awareness as whole-part relationships, which seems right. And it treats consciousness and awareness as existing in two forms: potential and actual. If the analogy holds, it allows us to say that consciousness already exists in potentia, in the parts that compose a conscious person, and that, analogously, awareness exists in potentia in the parts that compose a cell.

Now consider the NMfM Objection to emergent mentality, viz., that you can't get consciousness from something that is not conscious. For a Cartesian, this is right; res cogitans and res extensa are dichotomous. For Descartes one can never emerge from the other because he presupposes from the start that no potential for this transition exists. By contrast, Western philosophy and science offer a number of ways of understanding the transition from potential to actual. We could explore science-based analogies such as superposition, as in the "collapse « of the (probabilistic) Schrödinger wave equation to a particular macrophysical state. ${ }^{1}$ More broadly, Western metaphysics offers a rich legacy of ways to conceive the transition from potential to actual, for example in metaphysical systems inspired by Aristotle and in the dialectical philosophies of the German Idealists. These achievements offer crucial resources for conceptualizing the transition from potentially aware to actually aware. To the extent that the transition becomes comprehensible, the NMfM Objection is answered.

1 Quantum physics offers an empirical basis for thinking about the concepts of the actual and the possible or potential. »Potentially aware« and »actually aware « can exist in a way that is analogous to a quantum superposition. We know that the Copenhagen interpretation of quantum physics allows for states that are superpositions of actual and possible. In the famous thought experiment known as Schrödinger's cat, the cat exists in a state of superposition of dead::alive until a measurement causes the collapse of the wave function into either dead cat or alive cat. A so-called quantum computer (if one can be constructed) would be powerful because each bit (»qubit«) could manifest not two but three different states: on, off, or indeterminate. So far physicists have been able to prepare hundreds of individual atoms in individual »traps. « These matrices extend quantum potentials far beyond the scale at which they normally occur. 


\section{(3) Gradualist Panentheistic Panpsychism}

(1) God is a mental entity, the source of all mentality

(2) Everything is in God

(3) So all entities are mental entities.

At an academic conference in Munich in August 2017, Benedikt Göcke (among others) argued persuasively that the affirmation everything is in God is not sufficient to demarcate panentheism from various forms of classical theism. In any event, a position would surely not count as panentheism if it does not affirm (2) in some sense. For its part, (1) is an affirmation about God that is held in one form or another across most of the history of theology. For example, even if God has a body, God is not simply a material being. Applied to God, »mental entity« could mean a variety of different things: has (or essentially has) mental attributes, or is solely mental in the sense of having no physical attributes, or is the source of all mentality, or is mentality as such, etc. If (3) then follows, then from panentheism one can infer panpsychism.

Reflecting on the argument teaches us several things. First, its inference is not valid. ${ }^{2}$ Perhaps if (2) affirmed that »Everything is God, « the conclusion would follow. But that would be pantheism, not panentheism.

The argument also begs for a closer analysis of what is meant by mental entity. Given the imprecision of the term, it can only serve as a rough label for a set of different concepts. Thus Uwe Meixner writes in the Brüntrup and Jaskola collection, »The immediate consequence of this idea [panentheism] is that everything is in God (qua being in this total experience, which at the same time is the totality of all experiences), whether as an experience, as a subject of experience, or as an object of experience. «(Meixner 2017:399) Process theologians have explored these options in some detail. For example, Whitehead's »objective immortality « affirms that only the outcome of creative activity (concrescence) is in God, whereas Marjorie Suchocki's »subjective immortality« places the actual entity in its very becoming within God.

The ambiguity of »mental entity« and of the »in« in panentheism make it impossible to make a direct inference from panentheism to panpsychism in the full or »maximal« sense. ${ }^{3}$ Panpsychism does not follow if the panentheistic »in« is interpreted as the spatial »in,« nor if it is the finite $» i n \ll$ the

2 To succeed, (2) would need to read »Everything is God.« (And even then there are problems, as we can learn from Shankara's philosophy.) Panentheism is distinct from pantheism precisely because it does not make this assertion.

3 The question of whether panpsychism is helpful to the panentheist is an interesting one, although I will not have the chance to develop this argument fully here. Robert $\mathrm{C}$. Whittmore 
infinite. Unless and until it is shown that the »in « of panentheism requires each existing entity to be in itself a mental entity (to have mentality as one of its own properties), one is not compelled to affirm maximal panpsychism. Of course, one can attempt to defend maximal panpsychism on other grounds. But panentheism alone will not get one there.

Panentheism is helpful to the emergentist panpsychist, however. Even a minimal (panen)theism affirms divine creative intent and a continuing lure toward a telos that is consistent with the divine nature. Since the divine nature is or includes mentality, one would expect that the telos is or includes mentality as well. That created mentality may not be instantiated at the time of the big bang; it may be the product of a universe continually lured toward the divine nature. This result is consistent with what we now know about cosmic evolution: the mathematical laws of astrophysics that seem to reflect the constancy of God; the self-organizing patterns of biochemistry; the emergence of awareness and goal-oriented behavior at the dawn of the biosphere; and the gradual development of the capacity to know and worship God. Gradualist panentheistic panpsychism becomes the affirmation that God lures creation from »potentially aware« to »actually aware« in ways that preserve both the transcendence and the immanence of God.

\section{(4) „God in All Things « and the Ground of Mentality}

We have discussed all things in God; now we must turn to the second »in « of panentheism: God in all things.

(1) God is in all things.

(2) Wherever God present, mentality is present.

(3) Mentality is present in all things.

maintains that panpsychism can become panentheism or, even more strongly, that panpsychism may imply or entail panentheism. He uses a passage from John Fisk:

Panpsychism becomes panentheism in the realization that this »Life« manifest in all nature is »only a specialized form of the Universal Life, « which is that »eternal God indwelling in the universe, in whom we live and move and have our being.« For if, as noted earlier, God cannot be conceived as something outside the universe (as maintained in anthropomorphic theism), and if, as has been shown, we cannot identify Him or It with the universe phenomenally manifest (since this would be pantheism), then it must be that the one (theistic) alternative remaining is the truth: the universe is (as panentheism teaches) inside God! (John Fisk, quoted in Whittemore 1964: 303.)

Whittemore is right to note the inference from panpsychism to panentheism, adding only that the inference does not require maximal panpsychism; it works just as well from the standpoint of minimal panpsychism. 
Proposition (1) restates a major biblical theme, such as Acts 17:29, where Paul speaks of God as the one »in whom we live and move and have our being." The same assertion is present in most forms of Western theism. Göcke and others have shown that (1) is not distinctive to panentheism. But »God in all things « does express one of the two »in's« that even a more minimal panentheism must affirm. Again, (2) should be non-controversial for theists. If (3) follows, we have a second entailment from panentheism to panpsychism. Again, though, we must ask: panpsychism in what sense?

Skrbina put the point nicely:

There is a lingering and problematic sense in which Christian theology does allow for a weak form of panpsychism. If God is omnipresent, then he is obviously »in« all things; this points toward panentheism. If a portion of God is in a thing, and this portion assumes any sense of independent individuality, then this could qualify as a »monistic panpsychism.« (Skrbina 2005: 274 n. 24)

Skrbina recognizes that "panentheism can be confused with panpsychism." As we saw in the previous section, the two cannot be identified, but the former does imply, at minimum, an evolutionary sense of the latter.

Finally, Skrbina notes, »On the traditional view, God is omnipresent. If God represents spirit or mind, then all things can be said to contain mind-the mind of God.« (Skrbina 2005: 21) One wonders, then: does the second »in« of panentheism (God in the world) entail panpsychism in a stronger sense than the first (the world in God)?

In order to respond to this final objection to a gradualist panpsychism, it's helpful to take a short detour. Thomas Nagel is a non-theist who affirms a fundamental role for mind: »Mind, as a development of life, must be included as the most recent stage of this long cosmological history, and its appearance, I believe, casts its shadow back over the entire process and the constituents and principles on which the process depends. « (Nagel 2012: 8)

Nagel holds that the gradual appearance of mind across cosmological history requires one to affirm that mind was present in the universe from the beginning as a fundamental principle, analogous to the way that physicists affirm that physical laws and mass/energy were present from the beginning. He argues:

So if mind is a product of biological evolution — if organisms with mental life are not miraculous anomalies but an integral part of nature-then biology cannot

4 This is part of his non-emergence thesis, that is, his claim that there are no truly emergent properties of complex systems. 
be a purely physical science. The possibility opens up of a pervasive conception of the natural order very different from materialism - one that makes mind central, rather than a side effect of physical law. (Nagel 2012: 15)

Examining this passage, however, one begins to discern the disanalogy between physics and biology. It's true that physicists have to postulate that the fundamental physical particles and forces were present from the big bang, since they are essential for explaining even the first minutes of cosmic history. (See Weinberg 1977) We do not have to postulate the presence of mental entities, or properties such as awareness, in the same way. One might want to affirm that mind is »central « in the first million years of cosmic history, but there are no empirical reasons for doing so; it's not a postulate that one actually needs at that point.

That brings us back to the NMfM Objection. Anti-emergentists such as Nagel respond that, if we don't postulate the presence of mind from the beginning, it can't play a role in biological or psychological explanations. That might be true if the only options philosophy had were $x$ exists or $x$ does not exist. In fact, though, our resources include powerful theories of becoming, the movement from the one to the other. The Aristotelian tradition(s) offer compelling analyses of the status of potentiality and the transition from potential to actual. As a scientist, Stuart Kauffman ascribes to »the adjacent possible « a quasi-causal role in quantum physics and a role as formal or structural cause in biological evolution. (See Kauffman 2016) These contributions deflate the power of the NMfM Objection.

Once the NMfM Objection is set aside, an area of shared agreement becomes visible, namely, some ground for the gradual evolution of mentality must exist. Here we can affirm Nagel's contention: »We ourselves are large-scale, complex instances of something both objectively physical from outside and subjectively mental from the inside. Perhaps the basis for this identity pervades the world.« (Nagel 2012: 42) Interestingly, when one attempts to speak of this »basis, « it is difficult to avoid theological language. As Philip Goff notes at one point:

Or maybe, as Colin McGinn (1989) famously argued, human beings are constitutively incapable of grasping the nature of the properties underlying consciousness; it could nonetheless be that the emergence of consciousness from non-consciousness is intelligible to God if not to us. (Goff 2017)

More precisely, Goff might have written, »the emergence of consciousness from non-consciousness is intelligible to God ... and intelligible to us if we include, however hypothetically, the notion of God and divine creation. « Many panentheists hold that divine mind precedes the creation of the universe, so 
that creation manifests divine intention and other features of God's nature. The Westminster Shorter Catechism boldly formulates the telos of God's ongoing creative act: »Man's chief end is to glorify God, and to enjoy him forever." This goal does not require that mentality have been actually present in created beings from the first moment of cosmic history. But it does require that it have been present in potentia. That condition is met as long as the universe as a whole reflects the mind of its creator and the divine intent that mentality would eventually emerge and be manifested in the created world.

\section{Conclusion}

Thinking back over the argument, one realizes that this debate represents one particular instance of a much broader project: reflecting one's way to sophisticated responses that address core theological commitments on the one hand and the best of contemporary philosophy and science on the other. Success is impossible without participants who are willing to keep the doors open in both directions. The Richard Dawkinses and Dan Dennetts on the one side construe the natural world in such a way that mentality, and thus God, cannot play a fundamental role. Strong advocates of the separateness of God, Cartesian dualism, or interventionist divine action close down the discussion from the other side.

We are familiar with theologians willing to do the hard work in philosophy and science to open up the discussion, but equally important are scientists such as Stuart Kauffman and secular philosophers such as Thomas Nagel. In the following passage, note how deeply the non-theist Nagel enters into the conceptual world of theism:

My preference for an immanent, natural explanation is congruent with my atheism. But even a theist who believes God is ultimately responsible for the appearance of conscious life could maintain that this happens as part of a natural order that is created by God, but does not require further divine intervention. A theist not committed to dualism in the philosophy of mind could suppose the natural possibility of conscious organisms composed, perhaps supplemented by laws of psychophysical emergence. To make the possibility of conscious life a consequence of the natural order created by God while ascribing its actuality to subsequent divine intervention would then seem an arbitrary complication. Some form of teleological naturalism should for these reasons seem no less credible than an interventionist explanation, even to those who believe that God is ultimately responsible for everything. (Nagel 2017: 95) 
Nagel's words here beautifully reflect the goal of this paper, and in some ways also its outcome. I have embraced teleological naturalism by eschewing mind/ body dualisms and affirming mentality only where it is observable and plays some explanatory role. At the same time, I have pursued the questions from my standpoint as a panentheist. These two commitments required me to find a version of emergent mentality compatible with the double »in « of panentheism: all things in God and God in all things. The requirements of theology, philosophy, and science are best met, I argued, by a gradualist panpsychism that affirms the actuality of divine mind, the potentiality of mentality from the moment of creation, and the actual emergence of mentality over the course of evolution. ${ }^{5}$

\section{References}

Goff, P. (2017) »Panpsychism.« In: E.N. Zalta (ed.): The Stanford Encyclopedia of Philosophy, https://plato.stanford.edu/entries/panpsychism/\#AntiEmerArgu.

Kauffman, S.A. (2016) Humanity in a Creative Universe. New York: Oxford Univ. Press.

Meixner, U. (2017) »Idealism and Panpsychism.« In: G. Brüntrup and L. Jaskolla (eds.)

Panpsychism: Contemporary Perspectives. Oxford: Oxford University Press, 387-406.

Nagel, T. (2012) Mind and Cosmos: Why the Materialist Neo-Darwinian Conception of Nature is Almost Certainly False. New York: Oxford University Press.

Skrbina, D. (2005) Panpsychism in the West. Cambridge, MA: MIT.

Weinberg, S. (1977) The First Three Minutes. New York: Basic Books.

Whitehead, A.N. (1978) Process and Reality, corrected ed. New York: Free Press.

Whittemore, R.C. (1964) Makers of the American Mind: Three Centuries of American Thought and Thinkers. New York: Apollo Editions.

5 I am again grateful to Andrew M. Davis, who has worked as my research assistant on this paper. Our conversations together were important in formulating the key questions of this paper, and some of its key ideas emerged in discussions with him. (This is not to say that Mr. Davis agrees with the final thesis of the paper, however.) Every author knows the importance of the formative discussions that come just before writing, and it is a particular pleasure when these discussions can occur with one's graduate student. 